\title{
Relevansi Kurikulum PGMI Terhadap Capaian Pembelajaran Mahasiswa PGMI IAIN Metro
}

\author{
Nurul Afifah \\ Institut Agama Islam Negeri Metro \\ nurulafifah@metrouniv.ac.id
}

\begin{abstract}
Learning Outcomes (CP) are defined as abilities acquired through internalizing knowledge of attitudes, skills, competencies, and accumulated work experience. Learning Outcomes (CP) is a measure of what someone gets in completing the learning process both structurally and unstructured. Determination of learning outcomes must refer to three references / documents; namely KKNI, SNPT and SNPG. Furthermore, the formulation of learning outcomes is described in the Graduate Standards of Competency (SKL) which are expressed in four elements, namely: Attitudes, general skills, knowledge and special skills. This study aims to determine the relevance of the PGMI curriculum to the achievements of IAIN Metro student learning. The qualitative research is a type of library research. Techniques for collecting data through documentation, interviews and observation. Furthermore, the collected data was analyzed by qualitative descriptive techniques.Learning Outcomes in the curriculum of the PGMI IAIN Metro department in accordance with the provisions of KKNI, SNPT and SNPG are as follows; The four elements of graduation standards that must be mastered by students of the PGMI IAIN Metro are elements of attitude that are internalized during the learning process, elements of general skills are the ability to become teachers in general, the element of knowledge is in-depth knowledge in education, psychology and teaching and special skills that is ; the ability of graduates of study programs according to the field of science / expertise in this case is as a class teacher in $\mathrm{SD} / \mathrm{MI}$.
\end{abstract}

Keywords: Learning Outcomes, Curriculum, PGMI Department

Abstrak : Capaian Pembelajaran (CP) didefinisikan sebagai kemampuan yang diperoleh melalui internalisasi pengetahuan sikap, keterampilan, kompetensi, dan akumulasi pengalaman kerja. Capaian Pembelajaran (CP) merupakan alat ukur dari apa yang diperoleh seseorang dalam menyelesaikan proses belajar baik struktur maupun tidak terstruktur. Penetapan capaian pembelajaran harus mengacu pada tiga rujukan atau dokumen; yaitu KKNI, SNPT dan SNPG. Selanjutnya rumusan capaian pembelajaran dijabarkan dalam Standar Kompetensi Lulusan (SKL) yang dinyatakan dalam empat unsur yaitu : sikap, keterampilan umum, pengetahuan dan keterampilan khusus. Penelitian ini bertujuan untuk mengetahui relevansi kurikulum PGMI terhadap capaian pembelajaran mahasiswa IAIN Metro. Adapun penelitian kualitatif berjenis penelitian studi pustaka (library research). Tehnik pengumpulan data melalui dokumentasi, wawancara dan observasi. Selanjutnya data yang terkumpul

Ar-Riayah : Jurnal Pendidikan Dasar vol. 3, no. 1, 2019

IAIN Curup - Bengkulu 1 p ISSN 2580-362X; e ISSN 2580-3611

DOI: $10.29240 /$ jpd.v3i1.863 
dianalisis dengan teknik deskriptif kualitatif.Capaian Pembelajaran dalam kurikulum jurusan PGMI IAIN Metro sesuai dengan ketentuan KKNI, SNPT dan SNPG adalah sebagai berikut; empat unsur standar kelulusan yang harus dikuasai oleh mahasiswa jurusan PGMI IAIN Metro berupa unsur sikap yang dinternalisasikan saat proses pembelajaran, unsur keterampilan umum merupakan kemampuan menjadi guru secara umum, unsur pengetahuan merupakan penguasaan pengetahuan secara mendalam dalam bidang pendidikan, psikologi dan pengajaran dan unsur keterampilan khusus yaitu ; kemampuan lulusan program studi sesuai bidang keilmuan/keahlian dalam hal ini sebgai guru kelas di SD atau MI

Kata Kunci : Capaian Pembelajaran, Kurikulum, Jurusan PGMI

\section{PENDAHULUAN}

Tuntutan zaman saat ini semakin tinggi dan kompleks dalam semua sektor. Termasuk mutu pendidikan pada jenjang pendidikan tinggi. Sebagai salah bagian pendidikan tinggi, jurusan PGMI dituntut untuk bisa berkompetensi dengan jurusan-jurusan lain pada jenjang pendidikan tinggi di tingkat nasional bahkan internasional.

Secara konseptual, setiap jenjang kualifikasi dalam KKNI disusun berdasar empat parameter, yaitu: (1) keterampilan kerja, (2) cakupan keilmuan (pengetahuan), (3) metode dan tingkat kemampuan mengaplikasikan keilmuan, dan (4) kemampuan manajerial. Internalisasi dan akumulasi keempat parameter yang harus dicapai melalui proses pendidikan yang terstruktur atau melalui pengalaman kerja disebut dengan learning outcomes atau capaian pembelajaran.1

Capaian pembelajaran merupakan kemampuan yang diperoleh dari internalisasi pengetahuan, sikap, keterampilan, kompetensi dan akumulasi dengan pengalaman kerja. Parameter pencapaian pembelajaran tersebut seharusnya dimiliki oleh setiap lulusan sebuah institusi pendidikan melalui kurikulum yang diterapkan. Dengan demikian kurikulum yang diterapkan oleh sebuah program studi sangat berpengaruh pada kualitas lulusan prodi tersebut.

Jurusan Pendidikan Guru Madrasah Ibtidaiyah (PGMI) IAIN Metro telah menerapkan kurikulum 2014 berbasis KKNI sejak tahun pelajaran 2014/2015. Sebelum itu kurikulum yang diterapkan adalah kurikulum 2008 berbasis KBK (Kurikulum Berbasis Kompetensi). Dalam kurikulum 2014 berbasis KKNI pada jurusan PGMI dirumuskan beberapa capaian pembelajaran yang harus dimiliki oleh lulusan jurusan PGMI, yaitu; Menjadi guru kelas di MI/SD, berkepribadian yang baik, berpengetahuan luas dan mutakhir di bidang pendidikan dasar serta mampu menerapkan teori-teori

1 Depdiknas. Buku Pedoman Kerangka Kualifikasi Nasional Indonesia (Jakarta: Direktorat Jendral Pendidikan Tinggi, 2010), 18-19. 
pendidikan dan pembelajaran.2 Adapun profil pendukung capaian pembelajaran lulusan PGMI adalah sebagai peneliti, penulis, konsultan pendidikan dasar, pencipta dan pengembang alat peraga atau media di bidang pendidikan dasar dan wirausahawan.3

Fakta di lapangan sampai saat ini belum ada data yang pasti tentang berapa banyak lulusan jurusan PGMI Institut Agama Islam Negeri (IAIN) Metro yang bekerja sesuai dengan bidang keilmuannya. Apakah mereka bisa bersosialisasi dengan lingkungan masyarakatnya, bagaimana penerimaan masyarakat terkait alumni PGMI. Selain itu dari hasil observasi peneliti masih minimnya data-data berupa dokumen kurikulum, proses pembelajaran dan evaluasi untuk kurikulum saat ini (kurikulum 2014 berbasis KKNI).

Hal ini penting untuk dilakukan selain untuk memenuhi standar 5 akreditasi juga karena saat ini kita telah memasuki era Masyarakat Ekonomi Asia (MEA), dimana persaingan dunia kerja begitu ketat dan tidak bisa dibendung lagi. Demikian juga dengan dunia pendidikan, tahun ini sudah 10 universitas luar negeri ternama mendirikan cabang di Indonesia. Masuknya universitas luar negeri tersebut jika tidak diimbangi dengan peningkatan kualitas pendidikan di perguruan tinggi nasional akan menyebabkan turunnya minat masyarakat untuk menguliahkan anaknya di perguruan tinggi nasional dan berpindah ke perguruan tinggi internasional. Berdasarkan pada beberapa permasalahan di atas tulisan ini menyajikan hasil penelitian tentang bagaimana relevansi kurikulum jurusan PGMI terhadap capaian pembelajaran mahasiswa PGMI IAIN Metro.

\section{LANDASAN TEORI}

\section{Capaian Pembelajaran}

Dalam Kerangka Kualifikasi Nasional Indonesia (KKNI), Capaian Pembelajaran (CP) didefinisikan sebagai kemampuan yang diperoleh melalui internalisasi pengetahuan, sikap, keterampilan, kompetensi, dan akumulasi pengalaman kerja. Capaian Pembelajaran (CP) merupakan penera (alat ukur) dari apa yang diperoleh seseorang dalam menyelesaikan proses belajar baik struktur maupun tidak terstruktur. Maksudnya capaian pembelajaran ini bisa diperoleh saat proses pembelajaran di kelas maupun saat siswa tersebut di luar kelas di mana ia berada dalam lingkungan sosialnya.

Capaian pembelajaran terdiri dari tiga level: outcomes umum, outcomes program, dan outcomes mata kuliah (Palm Beach State College, 2013). Capaian pembelajaran didasarkan pada kebutuhan mahasiswa kebutuhan masyarakat, dan apa yang harus diketahui mahasiswa mengenai subjek tertentu (Learning

2 Peraturan Menteri Agama Republik Indonesia tentang Standar Kompetensi Lulusan pada Perguruan Tinggi Agama Islam Tahun 2012, 28.

3 Kurikulum Berbasis Kerangka Kualifikasi Nasional Indonesia (KKNI) Prodi PAI, PBA, PBI dan PGMI Jurusan Tarbiyah. Sekolah Tinggi Agama Islam Nergeri (STAIN) Jurai Siwo Metro 2014, 39. 
Management Corporation, 2013. Capaian pembelajaran sebaiknya berpusat pada siswa, spesifik bisa di ukur dan diamati. Maka dalam menyusun capaian pembelajaran hendaknya memakai rumus A-B-C-D (Audience, Behavior, Condition, Degree). 4

Pada awalnya rumusan Capaian Pembelajaran (CP) disusun dalam empat unsur yaitu pertama, sikap dan tata nilai, kedua; kemampuan kerja, ketiga; penguasaan pengetahuan, dan keempat; wewenang dan tanggung jawab. Untuk lebih jelasnya berikut uraian empat unsur capaian pembelajaran dalam KKNI :

a. Sikap dan tata nilai

Merupakan perilaku dan tata nilai yang merupakan karakter atau jati diri bangsa dan negara Indonesia. Sikap dan tata nilai ini terinternalisasi selama proses belajar, baik terstruktur atau tidak.

b. Kemampuan kerja

Merupakan wujud akhir dari transformasi potensi yang ada dalam akhir dari transformasi potensi yang ada dalam setiap individu pembelajar menjadi kompetensi atau kemampuan yang aplikatif dan bermanfaat.

c. Penguasaan pengetahuan

Merupakan informasi yang telah diproses dan diorganisasikan untuk memperoleh pemahaman, pengetahuan, dan pengalaman yang terakumulasi untuk memiliki suatu kemampuan.

d. Wewenang dan tanggung jawab

Merupakan konsekuensi seorang pembelajar yang telah memiliki kemampuan dan pengetahuan pendukungnya untuk berperan dalam masyarakat secara benar dan beretika.

\section{Standar Kompetensi Lulusan (SKL) dalam Capaian pembelajaran}

Standar kompetensi lulusan merupakan kriteria minimal tentang kualifikasi kemampuan lulusan yang mencakup sikap, pengetahuan, dan keterampilan yang dinyatakan dalam rumusan capaian pembelajaran lulusan.

Penetapan capaian pembelajaran harus mengacu pada tiga rujukan/dokumen. Yaitu Kerangka Kualifikasi Nasional Indonesia (KKNI) Standar Nasional Perguruan Tinggi (SNPT) dan Standar Nasional Pendidikan Guru (SNPG). Untuk selanjutnya rumusan capaian pembelajaran dijabarkan dalam Standar Kopetensi Lulusan (SKL) yang dinyatakan dalam empat unsur yaitu : Sikap, keterampilan umum, pengetahuan dan keterampilan khusus.

Unsur sikap dalam Capaian Pembelajaran (CP) SKL merupakan sikap yang dimiliki oleh lulusan pendidikan tinggi; unsur pengetahuan memiliki pengertian yang setara dengan unsur penguasaan pengetahuan dari Capaian Pembelajaran (CP) KKNI, yang harus dikuasai oleh lulusan program studi tersebut; unsur "keterampilan" merupakan gabungan unsur "kemampuan kerja"

4 Palm Beach State College, “Academic Management Manual: Outcomes AssessmentWorkbook."2013.8Availableat:www.palmbeachstate.edu/academicservices/docu ments/sectionl.pdf. diunduh tgl 01 Oktober 2018 
dan unsur "kewenangan dan tanggung jawab" dari deskripsi KKNI; unsur keterapilan khusus mencirikan kemampuan lulusan program studi sesuai bidang keilmuan/keahlian tertentu, sedang keterampilan umum mencirikan kemampuan lulusan sesuai tingkat dan jenis program pendidikan tidak bergantung pada bidang studinya.

\section{Kurikulum Berbasis Capaian Pembelajaran}

Kurikulum memiliki peran penting bagi perkembangan dunia pendidikan. Ibarat tubuh manusia kurikulum merupakan organ "jantung" dari manusia tersebut. Kurikulum merupakan sentral bagi semua jenjang pendidikan. Kurikulum dijadikan acuan bagi pendidik (guru) dalam melaksanakan dan meraih keberhasilan dalam proses pembelajaran. Selain itu kurikulum juga merupakan kombinasi antara pemikiran, perbuatan dan tujuan.

Dalam perspektif Pendidikan Tinggi, "kurikulum adalah seperangkat rencana dan pengaturan mengenai capaian pembelajaran lulusan, bahan kajian, proses dan penilaian yang digunakan sebagai pedoman penyelenggaraan program studi."(Permendikbud No. 49 tahun 2014) Kurikulum adalah sebuah program yang disusun dan dilaksanakan untuk mencapai capaian pembelajaran yang diharapkan program studi tertentu. Oleh karenanya, eksistensi sebuah kurikulum pendidikan tinggi sangat terkait langsung dengan aspek tujuan (learning outcome) yang diharapkan, bahan kajian yang disajikan, kegiatan pembelajaran yang dilakukan dosen dan mahasiswa, serta pola penilaian yang menjadi ukuran keberhasilan dari proses pembelajaran yang sedang atau telah selesai dilaksanakan.

Standar Nasional Pendidikan Tinggi (SN-DIKTI), sebagaimana diatur dalam Permenristekdikti Nomor 44 Tahun 2015 Pasal 1, menyatakan kurikulum adalah seperangkat rencana dan pengaturan mengenai capaian pembelajaran lulusan, bahan kajian, proses, dan penilaian yang digunakan sebagai pedoman penyelenggaran program studi. Kurikulum Pendidikan Tinggi merupakan amanah institusi yang harus senantiasa diperbaharui sesuai dengan perkembangan kebutuhan dan IPTEK yang dituangkan dalam capaian pembelajaran.

Dalam Tim Buku K-DIKTI dijelaskan secara singkat, perjalanan perubahan kurikulum pendidikan tinggi Indonesia sebagai berikut :

a. Kurikulum Berbasis Isi (KBI)

Pada tahun 1994 melalui Keputusan Menteri Pendidikan dan Kebudayaan Republik Indonesia Nomor 056/U/1994 tentang Pedoman Penyusunan Kurikulum Perguruan Tinggi dan Penilaian Hasil Belajar Mahasiswa, dikarenakan kurikulum yang mengutamakan ketercapaian penguasaan IPTEKS, oleh karenanya disebut Kurikulum Berbasis Isi (KBI). Pada model kurikulum ini ditetapkan mata kuliah wajib nasional pada program studi yang ada.

b.Kurikulum Berbasis Kompetensi (KBK) 
Kurikulum Berbasis Kompetensi (KBK) didefinisikan sebagai program pembelajaran yang diuraikan dengan jelas, konkret, memiliki tujuan yang bisa diukur yang memberi peluang setiap pembelajar yang terlibat dalam proses pembelajaran harus mampu mendemonstrasikan kemampuan seperti yang ditargetkan di akhir program. Depdiknas (2003) menjelaskan Kurikulum Berbasis Kompetensi (KBK) ialah kurikulum yang dirancang berdasarkan hasil belajar berupa kompetensi. Kompetensi itu sendiri didefinisikan sebagai kemampuan melakukan pekerjaan berdasarkan pengetahuan, keterampilan dan sikap kerja menurut ukuran atau standar tertentu yaitu standar kompetensi (SK). Penguasaan ilmunya disebut competence dan kemampuan mendemonstrasikan disebut competency. 5

c. Kurikulum Pendidikan Tinggi (KPT)

Dengan dorongan perkembangan global yang saat ini menuntut adanya pengakuan atas capaian pembelajaran yang telah disetarakan secara internasional dan dikembangkannya KKNI, maka dalam kurikulum tahun 2012 mengalami sedikit pergeseran dengan memberikan ukuran penyetaraan dengan capaian pembelajarannya. Kurikulum ini masih berdasar pada pencapaian kemampuan yang telah disetarakan untuk menjaga mutu lulusannya. Kurikulum ini dikenal dengan nama Kurikulum Pendidikan Tinggi (KPT).6

Kerangka Kualifikasi Nasional Indonesia, yang selanjutnya disingkat KKNI, adalah kerangka penjenjangan kualifikasi kompetensi yang dapat menyandingkan, menyetarakan, dan mengintegrasikan antara bidang pendidikan dan bidang pelatihan kerja serta pengalaman kerja dalam rangka pemberian pengakuan kompetensi kerja sesuai dengan struktur pekerjaan di berbagai sektor.

Secara konseptual, setiap jenjang kualifikasi dalam KKNI disusun oleh empat parameter, yaitu: (1) keterampilan kerja, (2) cakupan keilmuan (pengetahuan), (3) metode dan tingkat kemampuan mengaplikasikan keilmuan, dan (4) kemampuan manajerial. Internalisasi dan akumulasi keempat parameter yang harus dicapai melalui proses pendidikan yang terstruktur atau melalui pengalaman kerja disebut dengan learning outcomes atau capaian pembelajaran.

Rumusan Capaian Pembelajaran lulusan harus dikaji kesetaraannya terhadap deskripsi Capaian Pembelajaran dari KKNI, dan dikaji terhadap Standar Isi Pembelajaran dari Stansar Nasional DIKTI. Penyusunan Capaian Pembelajaran merupakan bagian dari evaluasi dan pengembangan kurikulum.

5 Imroatus Solikhah "KKNI Dalam Kurikulum Berbasis Learning Outcome” dalam LINGUA, Vol 12, No. 1 Maret 2015, 4

6 Tim K-DIKTI, Buku Kurikulum Pendidikan Tinggi Direktorat Pembelajaran dan Kemahasiswaan (Jakarta: Direktorat Jenderal Pendidikan Tinggi Kementerian Pendidikan dan Kebudayaan, 2014), 15-16. 
Dalam program studi yang telah beroperasi penyusunan Capaian Pembelajaran dilakukan dalam konteks evaluasi dan pengembangan kurikulum, yaitu Capaian Pembelajaran yang telah dimiliki atau diharapkan dimiliki oleh lulusan perlu dievaluasi kessuaiannya dengan ketentuan yang berlaku dan terhadap perkembangan kebutuhan penggunaserta perkembangan keahlian atau keilmuan.

\section{METODE PENELITIAN}

Penelitian ini berjenis penelitian studi pustaka (library research) dan kualitatif. Tehnik pengumpulan data melalui dokumentasi, wawancara dan observasi. Selanjutnya data yang terkumpul dianalisis dengan teknik deskriptif kualitatif

\section{HASIL PENELITIAN}

Jurusan pendidikan Guru madrasah Ibtidaiyah (PGMI) IAIN Metro berdiri pada tahun 2007. Cikal bakal program Studi/Jurusan ini pada awalnya berupa program Diploma II PGMI dan pada Tahun 2007 berkembang menjadi progran Strata satu. Seiring dengan perkembangan zaman dan kebutuhan masyarakat, khususnya tingkat regional se-propinsi Lampung, akan peningkatan profesionalisme tenaga di bidang pendidikan guru Madrasah Ibtidaiyah, STAIN Jurai Siwo Metro meresponnya dengan pembukaan program strata satu Pendidikan Guru Madrasah Ibtidaiyah (PGMI) ini.

Legalitas dan izin operasional Program Studi Pendidikan Guru Madrasah Ibtidaiyah (PGMI) Stain Jurai Siwo Metro, Lampung berdasarkan surat keputusan Direktur Jenderal Pendidikan Islam, nomor Dj.I/257/2007 tentang izin penyelengaraan Program Pendidikan Guru Madrasah Ibtidaiyah (PGMI) jenjang Strata Satu (S1) pada Perguruan Tinggi Agama Islam (PTAI). Keputusan ini ditetapkan di Jakarta pada tanggal 10 Juli 2007.7 Pada tahun 2009, Prodi/jurusan PGMI STAIN Jurai Siwo Metro mendapat Izin perpanjangan penyelenggaraan program studi/jurusan melalui surat Keputusan direktur Jenderal pendidikan Islam nomor Dj.I/485/2009.8 Selanjutnya pada tahun 2012, prodi/ jurusan PGMI STAIN Jurai Siwo Metro mendapat Izin

7 Surat Keputusan Direktur Jenderal Pendidikan Islam Departemen Agama RI Nomor Dj.I/257/2007 tentang Izin Penyelenggaraan Program Pendidikan Guru Madrasah Ibtidaiyah (PGMI) Jenjang Strata Satu (S1) pada Perguruan Tinggi Agama Islam (PTAI).

8 Surat Keputusan Direktur Jenderal Pendidikan Islam Departemen Agama RI Nomor Dj.I/485/2009 tentang perpanjangan izin penyelenggaraan program studi Pendidikan Guru Madrasah Ibtidaiyah (PGMI) jenjang Strata Satu (S1) pada Perguruan Tinggi Agama Islam Negeri (PTAIN) 
perpanjangan penyelenggaraan program studi/jurusan melaui surat keputusan direktur Jenderal Pendidikan Islam Nomor 561 tahun 2012.9

\section{Kurikulum Jurusan PGMI IAIN Metro}

Jurusan PGMI dalam fakta historisnya telah melaksanakan pergantian kurikulum sebanyak tiga kali, yaitu :

a. Kurikulum 2008

Kurikulum 2008 merupakan bentuk pengejawantahawan dari kurikulum nasional pendidikan tinggi yaitu kurikulum berbasis kompetensi $(\mathrm{KBK})$. Kurikulum ini diberlakukan pertama kali sejak izin operasional jurusan PGMI pada tahun 2007. Saat itu institusi lembaga masih merupakan sekolah tinggi agama Islam (STAIN) Jurai Siwo Metro. Demikian juga jurusan PGMI masih berupa Program Studi (Prodi).

Pada kurikulum berbasis kompetensi (KBK) tidak ditetapkan batasan keilmuan yang harus dikuasai oleh mahasiswa. Cara mengukur ketercapaian kompetensi oleh mahasiswa adalah setiap mata kuliah diurai berdasar kompetensi dasar (SK) dan kompetensi dasar (KD). Selanjutnya rumusan kompetensi yang tertuang pada setiap mata kuliah tersebut yang seharusnya dicapai oleh mahasiswa.

Muatan mata kuliah pada Kurikulum Berbasis Kompetensi (KBK) terdiri dari atas kurikulum inti dan institusional. Dalam mengimplementasikan Kurikulum Berbasis Kompetensi ditetapkan kompetensi utama oleh kesepakatan bersama antara kalangan perguruan tinggi, masyarakat profesi, dan pengguna lulusan. Sedangkan kompetensi pendukung lainnya, ditetapkan oleh perguruan tinggi sendiri.

Adapun muatan mata kuliah pada Kurikulum 2008 program studi pendidikan guru madrsah ibtidaiyah (PGMI) STAIN Jurai Siwo Metro sudah mengacu pada lima pilar pendidikan yang dikembangkan dari pilar UNESCO dan disesuaikan dengan Keputusan Mendiknas No. 232/U/2000, yang teruraikan sebagaimana berikut:

1) MPK (Mata Kuliah Pengembangan Kepribadian) terdiri atas lima mata kuliah yaitu : Pancasila, Pendidikan Kewargaan, IAD,ISD,IBD, Filsafat Uum dan Psikologi Umum.

2) MKK (Mata Kuliah Keilmuan dan Keterampilan)

Mata kuliah dalam rumpun ini merupakan mata kuliah yang dipersiapkan untuk calon guru di Madrasah Ibtidaiyah. Sehingga muatannya adalah semua materi yang dijadikan mata pelajaran di madrasah Ibtidaiyah, antara lain : IPS, IPA, Matematika, Bahasa Indonesia, Al-Qur'an Hadits, Fiqih, Aqidah Akhlak, Sejarah

9 Surat Keputusan Direktur Jenderal Pendidikan Islam Nomor 561 tahun 2009 tentang perpanjangan izin penyelenggaraan program studi Pendidikan Guru Madrasah Ibtidaiyah (PGMI) jenjang Strata Satu (S1) pada Perguruan Tinggi Agama Islam Negeri (PTAIN) Tahun 2012 pada tanggal 15 Mei 2012. 
Kebudayaan Islam, Bahasa Arab, PPKN, Pendidikan Seni, Pendidikan Oerkes dan Pendidikan keterampilan.

3) MKB (Mata Kuliah Keahlian Berkarya)

Mata kuliah pada rumpun ini dipersiapkan agar mahasiswa mempunyai keahlian dan berkarya dalam menjalani profesinya sebagai guru. Untuk rupun mata kuliah ini adalah : ilmu pendidikan, evaluasi pendidikan, administrasi pendidikan, supervisi pendidikan, SPI, filsafat pendidikan Islam, psikologi pendidikan, psikologi perkembangan, psikologi agama, statistik pendidikan 1,2. metodologi penelitian pendidikan, PTK, perencanaan pembelajaran, manajemen pendidikan, media pembe;ajaran, strategi pembelajaran, BK dan telaah kurikulum.

5) MPB (Mata Kuliah Perilaku Berkarya)

Termasuk dalam rumpun ini adalah mata kuliah PPL 1, PPL 2, Ilmu Dakwah, Bhs Lampung dan Skripsi.

6) MBB (Mata Kuliah Berkehidupan Bermasyarakat)

Untuk mata kuliah ini hanya satu yaitu KKN

7) MKPK (Mata Kuliah Pilihan Konsentrasi)

Untuk mata kuliah pilihan antara lain : Apresiasi sastra Indonesia, Konsep dasarKimia, Tafsir tarbawi dan Ushul Fiqh.

b. Kurikulum 2014 berbasis KKNI (Peralihan)

Sejak Direktorat jendral Perguruan Tinggi (DIKTI) mewajibkan semua perguruan tinggi baik negeri atau swasta untuk menerapkan kurikulum berbasis KKNI pada tahun 2013. Maka mulai tahun akademik 2015/2016 fakultas tarbiyah dan ilmu keguruan (FTIK) IAIN Metro mulai menerapkan kurikulum 2014 berbasis KKNI. Istilah peralihan peneliti pakai karena pada saat pemberlakuan kurikulum ini status institusi beralis status dari Sekolah Tinggi Agama Islam Negeri (STAIN) Jurai Siwo Metro menjadi Institut Agama Islam Negeri (IAIN) Metro. Demikian juga untuk sebutan Program Studi (prodi) beubah menjadi jurusan PGMI.

Pemberlakuan kurikulum 2014 berbasis KKNI pada saat itu masih belum sempurna, hal ini disebabkan karena penyusunan kurikulum masih sebatas deskripsi capaian pembelajaran KKNI level 6 dan belum sampai pada analisis keterkaian capaian pembelajaran Lulusan (CPL) dengan KKNI dan profil lulusan. Namun secara umum pembagian distribusi mata kuliah mulai disesuaian dengan tuntutan dalam KKNI.

Perubahan kurikulum berbasis kompetensi (KBK) pada kurikulum berbasis KKNI telah membawa banyak perubahan pada distribusi mata kuliah. Ada beberapa mata kuliah yang dihapus karena dinilai kurang relevan dengan tercapainya profil lulusan, misalnya mata kuliah Psikologi Umum, Psikologi Agama, Supervisi Pendidikan, Sejarah Pendidikan Islam, dan Bimbingan Konseling beberapa mengalami pengurangan dan penambahan SKSnya dan ada juga beberapa yang dirubah namanya namun secara konten tetap sama. Misalnya Bahasa Arab 1 berubah jadi Bahasa Arab Dasar, 
Bahasa Inggris 1 menjadi Bahasa Inggris Dasar, dan seterusnya. Beberapa mata kuliah juga ditambahkan dalam kurikulum ini antara lain Kepramukaan dan Pembelajaran Tematik. Dengan pertimbangan kedua mata kuliah tersebut diajarkan pada Sekolah Dasar atau Madrasah Ibtidaiyah.

Alasan beberapa perubahan mata kuliah dimaksudkan untuk lebih fokus lagi dalam mempersiapkan calon lulusannya, yaitu menjadi guru kelas. Sehingga untuk materi perkuliahan difokuskan pada materi yang diajarkan di sekolah dasar (SD atau MI).

Capaian pembelajaran dalam kurikulum 2014 telah disesuaikan dengan amanah kurikulum KKNI. Untuk capaian pembelajaran harus merujuk pada tiga dokumen penting yaitu : dokumen KKNI, SNPT dan SNPG. Untuk selanjutnya rumusan capaian pembelajaran dijabarkan dalam Standar Kopetensi Lulusan (SKL) yang dinyatakan dalam empat unsur yaitu : Sikap, keterampilan umum, pengetahuan dan keterampilan khusus.

c. Kurikulum KKNI

Kurikulum ini merupakan penyempurnaan dari kurikulum yang telah diberlakukan sebelumnya yaitu kurikulum 2014 berbasis KKNI. Kurikulum KKNI mulai diberlakukan di jurusan PGMI pada tahun akademik 2018-2019. Setelah diadakan beberapa kali lokakarya kurikulum, workshop kurikulum maka berhasilah dibuat dokumen pedoman kurikulum jurusan PGMI. Pedoman kurikulum ini telah mengalami beberapa kali revisi sehingga mendekati kesempurnaan. Jika pada dokumen pedoman kurikulum kurikulum KKNI sebelumnya pembahasan masih sebatas capaian pembelajaran lulusan (CPL) saja, maka dalam pedoman kurikulum saat ini sudah bisa dikatakan lengkap. Capaian pembelajaran lulusan (CPL) sudah dikembangkan lebih jauh lagi menjadi capaian pembelajaran mata kuliah (CPMK) dan sub CPMK, hingga analisis pembangian waktunya. Demikian juga untuk muatan mata kuliah telah disesuaikan dengan standar capaian pembelajaran, dengan bobot muatan terbanyak pada mata kuliah program studi sebanyak 77 SKS. Untuk lebih jelasnya terurai pada tabel berikut ini :

Tabel 1. Pengejawantahan Capaian Pembelajaran Lulusan (CPL) Ke dalam Capaian Pembelajaran Mata Kuliah (CPMK)

\begin{tabular}{|c|c|}
\hline CPL & SUB-CPL (CPMK) \\
\hline \multicolumn{2}{|l|}{ SIKAP } \\
\hline \multirow{4}{*}{$\begin{array}{l}\text { 1. Bertaqwa kepada Tuhan } \\
\text { Yang Maha Esa dan } \\
\text { mampu menunjukkan } \\
\text { sikap religius }\end{array}$} & $\begin{array}{l}\text { 1. Memahami perintah dan larangan pada } \mathrm{Al} \\
\text { Qur'an dan Hadist }\end{array}$ \\
\hline & $\begin{array}{l}\text { 2. Mengamalkan perintah dan larangan pada } \mathrm{Al} \\
\text { Qur'an dan Hadist }\end{array}$ \\
\hline & Mampu membaca dan menulis Al Qur'an \\
\hline & 4. Memahami dan menghayati makna yang \\
\hline
\end{tabular}


2. Menjunjung tinggi nilai kemanusiaan dalam menjalankan tugas berdasarkan agama,moral, dan etika

3. Berkontribusi dalam peningkatan mutu kehidupan bermasyarakat, berbangsa, bernegara, dan kemajuan peradaban berdasarkan Pancasila

4. Berperan sebagai warga negara yang bangga dan cinta tanah air, memiliki nasionalisme serta rasa tanggungjawab pada negara dan bangsa

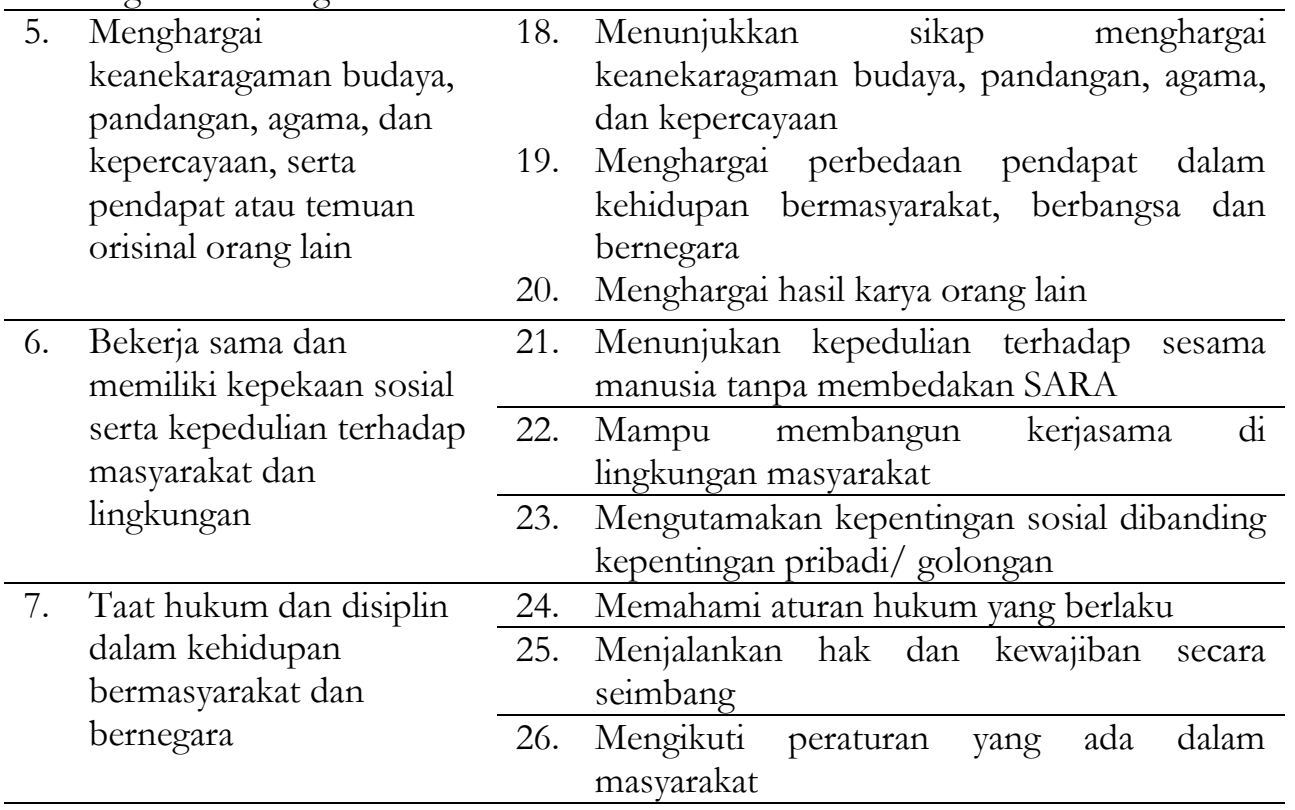

terkandung dalam Alqur'an dan Hadist

5. Menunjukkan sikap religius sesuai dengan ajaran agama Islam

6. Mengetahui sejarah kebudayaan Islam sebagai refleksi dan panutan dalam kehidupan

7. Memahami sejarah kebudayaan Islam sebagai refleksi dan panutan dalam kehidupan

8. Memiliki perilaku taat hukum Islam dalam kehidupan sosial

9. Menunjukkan nilai-nilai kemanusiaan dalam kehidupan sehari-hari berdasarkan ajaran agama Islam

10. Membangun sikap peserta didik yang bermoral dan beretika berdasarkan AlQur'an dan Hadist

11. Mengembangkan sikap untuk membangun bangsa dan negara berdasarkan nilai-nilai pancasila

12. Menampilkan sikap yang sesuai dengan nilainilai pancasila dalam kehidupan sehari-hari

13. Menampilkan sikap yang bangga cinta dan tanah air

14. Memiliki rasa nasionalisme serta tanggung jawab bangsa dan negara Indonesia 


\begin{tabular}{|c|c|c|c|}
\hline 8. & $\begin{array}{l}\text { Menginternalisasi } \\
\text { norma, dan } \\
\text { akademik }\end{array}$ & 28. & $\begin{array}{l}\text { Memahami nilai norma dalam aktivitas } \\
\text { pendidikan } \\
\text { Mematuhi etika dan aturan akademik dalam } \\
\text { menjalankan aktivitas pendidikan }\end{array}$ \\
\hline \multirow[t]{2}{*}{9.} & \multirow{2}{*}{$\begin{array}{l}\text { Menunjukkan sikap } \\
\text { bertanggungjawab atas } \\
\text { pekerjaan di bidang } \\
\text { keahliannya secara } \\
\text { mandiri }\end{array}$} & 29. & $\begin{array}{l}\text { Menganut sikap bertanggugjawab atas } \\
\text { pekerjaan yang dilakukan secara mandiri }\end{array}$ \\
\hline & & 30. & $\begin{array}{l}\text { Menampilkan sikap bertanggungjawab atas } \\
\text { pekerjaan yang dilakukan berdasarkan ajaran } \\
\text { agama Islam }\end{array}$ \\
\hline \multirow[t]{6}{*}{10.} & \multirow{6}{*}{$\begin{array}{l}\text { Menginternalisasi } \\
\text { semangat kemandirian, } \\
\text { kejuangan,dan } \\
\text { kewirausahaan }\end{array}$} & 31. & an wirausaha berbasis syariah \\
\hline & & 32. & $\begin{array}{l}\text { Menjalankan perekonomian berlandaskan } \\
\text { paradigma nilai-nilai Pancasila }\end{array}$ \\
\hline & & 33. & $\begin{array}{l}\text { Menunjukan karakter kewirausahaan yang } \\
\text { nasionalis dan pancasilais }\end{array}$ \\
\hline & & 34. & $\begin{array}{l}\text { gat kemandirian yang } \\
\text { yerah dalam menjaga }\end{array}$ \\
\hline & & 35. & $\begin{array}{l}\text { Mengkomunikasikan kewirausahaan yang } \\
\text { digeluti ke pangsa pasar local, nasional dan } \\
\text { global }\end{array}$ \\
\hline & & 36. & $\begin{array}{l}\text { Merangsang terbentuknya wirausaha yang } \\
\text { jujur, mandiri dan kreatif }\end{array}$ \\
\hline \multirow[t]{2}{*}{11.} & \multirow{2}{*}{$\begin{array}{l}\text { Memahami dirinya secara } \\
\text { utuh sebagai pendidik di } \\
\text { MI/SD; }\end{array}$} & 37. & ndidik di MI/SD \\
\hline & & 38. & $\begin{array}{l}\text { bagai pendidik yang } \\
\text { erta didik }\end{array}$ \\
\hline \multirow[t]{2}{*}{12.} & \multirow{2}{*}{$\begin{array}{l}\text { Memiliki kepekaan sosial } \\
\text { dan kepedulian terhadap } \\
\text { perkembangan peserta } \\
\text { didik di MI/SD }\end{array}$} & 39. & $\begin{array}{l}\text { Memahami karateristik peserta didik di } \\
\text { MI/SD }\end{array}$ \\
\hline & & 40. & $\begin{array}{l}\text { Memiliki kemampuan dalam membantu } \\
\text { permasalahan yang dihadapi peserta didik }\end{array}$ \\
\hline \multicolumn{4}{|c|}{ KETERAMPILAN UMUM } \\
\hline \multirow[t]{4}{*}{1.} & \multirow{4}{*}{$\begin{array}{l}\text { Mampu menerapkan } \\
\text { pemikiran logis, kritis, } \\
\text { sistematis, dan inovatif } \\
\text { dalam konteks } \\
\text { pengembangan atau } \\
\text { implementasi ilmu } \\
\text { pengetahuan dan teknologi } \\
\text { yang memperhatikan dan } \\
\text { menerapkan nilai } \\
\text { humaniora yang sesuai } \\
\text { dengan bidang keahliannya }\end{array}$} & 41. & $\begin{array}{l}\text { berfikir secara logis dan bijak dalam } \\
\text { kan ilmu pengetahuan dan teknologi } \\
\text { memperhatikan nilai-nilai humaniora }\end{array}$ \\
\hline & & 42. & $\begin{array}{l}\text { Mampu berfikir kritis dalam mengkaji } \\
\text { berbagai permasalahan dalam bidang ilmu } \\
\text { pada tingkat pendidikan dasar di MI/SD }\end{array}$ \\
\hline & & 43. & $\begin{array}{l}\text { Mampu menggabungkan konsep ilmu } \\
\text { pengetahuan secara sistematis dalam bidang } \\
\text { pendidikan dasar di MI/SD }\end{array}$ \\
\hline & & 44. & $\begin{array}{l}\text { Mampu menggunakan ilmu pengetahuan dan } \\
\text { teknologi yang inovatif dalam bidang } \\
\text { pendidikan dasar di MI/SD }\end{array}$ \\
\hline \multirow[t]{2}{*}{2.} & \multirow{2}{*}{$\begin{array}{l}\text { Mampu menunjukkan } \\
\text { kinerja mandiri, bermutu, } \\
\text { dan terukur }\end{array}$} & 45. & Memahami standar mutu Pendidikan \\
\hline & & 46. & $\begin{array}{l}\text { Membuat perencanaan pembelajaran yang } \\
\text { sistematis dan terukur dengan acuan } \\
\text { kurikulum yang berlaku }\end{array}$ \\
\hline
\end{tabular}




\begin{tabular}{|c|c|c|}
\hline & $\begin{array}{l}\text { 47. Memahami teknik evaluasi dan perbaikan } \\
\text { pembelajaran }\end{array}$ \\
\hline & & 48. Menunjukan inovasi pembelajaran \\
\hline \multirow[t]{6}{*}{3.} & \multirow{6}{*}{$\begin{array}{l}\text { Mampu mengkaji } \\
\text { implikasi pengembangan } \\
\text { atau implementasi ilmu } \\
\text { pengetahuan teknologi } \\
\text { yang memperhatikan dan } \\
\text { menerapkan nilai } \\
\text { humaniora sesuai dengan } \\
\text { keahliannya berdasarkan } \\
\text { kaidah, tata cara dan etika } \\
\text { ilmiah dalam rangka } \\
\text { menghasilkan solusi, } \\
\text { gagasan, desain atau kritik } \\
\text { seni }\end{array}$} & 49. Merancang pembelajaran berbasis karakter \\
\hline & & $\begin{array}{l}\text { 50. Membuat penelitian tindakan kelas untuk } \\
\text { merekontruksi kelemahan pembelajaran }\end{array}$ \\
\hline & & $\begin{array}{l}\text { 51. Membandingkan nilai-nilai humaniora sesuai } \\
\text { keahliannya }\end{array}$ \\
\hline & & $\begin{array}{l}\text { 52. Mampu memberikan gagasan atau ide yang } \\
\text { terkait dengan pengembangan ilmu } \\
\text { pendidikan dasar di MI/SD }\end{array}$ \\
\hline & & $\begin{array}{l}\text { 53. Mengaplikasikan konsep ilmu pengetahuan } \\
\text { untuk menghasilkan solusi, gagasan, desain } \\
\text { sesuai dengan perkembangan teknologi }\end{array}$ \\
\hline & & $\begin{array}{l}\text { liki jiwa seni yang sesuai dengan nilai- } \\
\text { umaniora }\end{array}$ \\
\hline \multirow[t]{6}{*}{4.} & \multirow{6}{*}{$\begin{array}{l}\text { Mampu melakuan riset } \\
\text { dan menyusun deskripsi } \\
\text { saintifik hasil kajiannya } \\
\text { dalam bentuk skripsi atau } \\
\text { laporan tugas akhir, dan } \\
\text { mengunggahnya dalam } \\
\text { laman perguruan tinggi }\end{array}$} & $\begin{array}{l}\text { In makalah/ artikel ilmiah sebagai } \\
\text { ugas pembelajaran/ perkuliahan }\end{array}$ \\
\hline & & 56. Menyusun proposal penelitian untuk skripsi. \\
\hline & & $\begin{array}{l}\text { 57. Mampu memilih dan menggunakan metode } \\
\text { pengumpulan data dalam penelitian }\end{array}$ \\
\hline & & $\begin{array}{l}\text { 58. Mengolah dan menganalisis data hasil } \\
\text { penelitian, secara kuantitatif dan/atau } \\
\text { kualitatif }\end{array}$ \\
\hline & & $\begin{array}{l}\text { un laporan hasil penelitian dalam } \\
\text { skripsi }\end{array}$ \\
\hline & & $\begin{array}{l}\text { munkasikan hasil penelitian skripsi } \\
\text { san dan/atau tulisan }\end{array}$ \\
\hline \multirow[t]{3}{*}{5.} & \multirow{3}{*}{$\begin{array}{l}\text { Mampu mengambil } \\
\text { keputusan secara tepat } \\
\text { dalam konteks } \\
\text { penyelesaian masalah di } \\
\text { bidang keahliannya, } \\
\text { berdasarkan hasil analisis } \\
\text { informasi dan data }\end{array}$} & $\begin{array}{l}\text { 61. Mampu menganalisis informasi untuk } \\
\text { menyelesaikan masalah pendidikan di } \\
\text { MI/SD }\end{array}$ \\
\hline & & $\begin{array}{l}\text { 62. Mampu mengkualifikasi data untuk } \\
\text { mengambil keputusan dalam penyelesaian } \\
\text { masalah pendidikan sesuai bidang } \\
\text { keahliannya }\end{array}$ \\
\hline & & $\begin{array}{lllr}\text { 63. Mampu mengambil keputusan } & \text { dengan } \\
\text { menggunakan logika matematika } & \text { dalam } \\
\text { permasalahan sehari-hari } & \\
\end{array}$ \\
\hline \multirow[t]{3}{*}{6.} & \multirow{3}{*}{$\begin{array}{l}\text { Mampu memelihara dan } \\
\text { mengembangkan jaringan } \\
\text { kerja dengan } \\
\text { pembimbing, kolega, } \\
\text { sejawat baik di dalam } \\
\text { maupun di luar } \\
\text { lembaganya }\end{array}$} & $\begin{array}{l}\text { 64. Mampu berkomunikasi dengan lingkungan } \\
\text { kerja dan diluar lingkungan kerja dengan } \\
\text { menggunakan Bahasa Indonesia yang baik } \\
\text { dan benar }\end{array}$ \\
\hline & & $\begin{array}{l}\text { 65. Mampu mengerti dan memahami } \\
\text { penggunaan Bahasa Inggris secara dasar }\end{array}$ \\
\hline & & $\begin{array}{l}\text { 66. Mampu berkomunikasi dengan lingkungan } \\
\text { kerja dan di luar lingkungan kerja dengan }\end{array}$ \\
\hline
\end{tabular}




\begin{tabular}{|c|c|}
\hline & $\begin{array}{lll}\text { menggunakan bahasa internasional yaitu } \\
\text { Bahasa Inggris }\end{array}$ \\
\hline & $\begin{array}{l}\text { 67. Mampu mengerti dan memahami } \\
\text { penggunaan Bahasa Arab secara dasar }\end{array}$ \\
\hline & $\begin{array}{l}\text { 68. Mampu berkomunikasi dengan lingkungan } \\
\text { kerja dan di luar lingkungan kerja dengan } \\
\text { menggunakan Bahasa Arab }\end{array}$ \\
\hline & $\begin{array}{l}\text { 69. Mampu bekerjasama dengan pembimbing, } \\
\text { kolega, sejawat di dalam atau di luar } \\
\text { lembaganya }\end{array}$ \\
\hline & $\begin{array}{l}\text { 70. Berpengalaman dalam menganalisis dan } \\
\text { menyeleaikan masalah dengan studi lapangan }\end{array}$ \\
\hline \multirow{3}{*}{$\begin{array}{l}\text { 7. } \text { Mampu } \\
\text { bertanggungjawab atas } \\
\text { pencapaian hasil kerja } \\
\text { kelompok dan melakukan } \\
\text { supervisi dan evaluasi } \\
\text { terhadap penyelesaian } \\
\text { pekerjaan yang ditugaskan } \\
\text { kepada pekerja yang } \\
\text { berada di bawah } \\
\text { tanggungjawabnya } \\
\end{array}$} & $\begin{array}{l}\text { 71. Memahami konsep pengelolaan lembaga } \\
\text { pendidikan }\end{array}$ \\
\hline & \begin{tabular}{llrl} 
72. & Memahami aturan/ & \multicolumn{2}{c}{ rambu-rambu } \\
pelaksanaan supervisi & pendidikan dan \\
evaluasi pembelajaran & & \\
\end{tabular} \\
\hline & $\begin{array}{l}\text { 73. Mampu bekerja secara individu dan } \\
\text { kelompok dengan pemahaman kelebihan dan } \\
\text { kelebihan sistem ekonomi }\end{array}$ \\
\hline \multirow{4}{*}{$\begin{array}{l}\text { 8. Mampu melakukan proses } \\
\text { evaluasi diri terhadap } \\
\text { kelompok kerja yang } \\
\text { berada dibawah tanggung } \\
\text { jawabnya, dan mampu } \\
\text { mengelola pembelajaran } \\
\text { secara mandiri }\end{array}$} & $\begin{array}{l}\text { 74. Melaksanakan feed back atas pembelajaran } \\
\text { yang dilakukan }\end{array}$ \\
\hline & $\begin{array}{l}\text { 75. Membangun partisipasi } \\
\text { pembelajaran secara aktif }\end{array}$ \\
\hline & $\begin{array}{l}\text { 76. Mengelola belajar dan pembelajaran secara } \\
\text { mandiri }\end{array}$ \\
\hline & $\begin{array}{l}\text { 77. Mampu mengevaluasi proses pembelajaran di } \\
\text { MI/SD }\end{array}$ \\
\hline \multirow{3}{*}{$\begin{array}{l}\text { 9. Mampu } \\
\text { mendokumentasikan, } \\
\text { menyimpan, } \\
\text { mengamankan, dan } \\
\text { menemukan kembali data } \\
\text { untuk menjamin } \\
\text { kesahihan dan mencegah } \\
\text { plagiasi } \\
\end{array}$} & 78. Mengidentifikasi data secara baik dan benar \\
\hline & 79. Mengolah data sesuai dengan karateristiknya \\
\hline & $\begin{array}{l}\text { 80. Mempertanggungjawabkan } \\
\text { diperoleh secara ilmiah }\end{array}$ \\
\hline \multicolumn{2}{|l|}{ PENGETAHUAN } \\
\hline \multirow{3}{*}{$\begin{array}{l}\text { 1. Memahami landasan } \\
\text { filosofis, yuridis, historis, } \\
\text { sosiologis, psikologis, dan } \\
\text { empiris pendidikan }\end{array}$} & $\begin{array}{l}\text { 81. Memahami landasan filosofis, yuridis, } \\
\text { historis, sosiologis, psikologis, dan empiris } \\
\text { dalam pendidikan }\end{array}$ \\
\hline & $\begin{array}{l}\text { 82. Mengidentifikasi dasar filosofis-yuridis } \\
\text { penyelenggaraan pendidikan/ mata pelajaran } \\
\text { beserta turunannya }\end{array}$ \\
\hline & 83. Memahami kajian filsafat pendidikan \\
\hline
\end{tabular}




\begin{tabular}{|c|c|}
\hline & \multirow{3}{*}{$\begin{array}{ll}\text { 84. } & \text { Memahami karakter lingkungan pendidikan } \\
\text { 85. } & \text { Menerapkan ilmu pendidikan secara empiris } \\
\end{array}$} \\
\hline & \\
\hline & \\
\hline \multirow{3}{*}{$\begin{array}{l}\text { Memahami konsep, } \\
\text { instrumentasi, dan praksis } \\
\text { psikologi pendidikan }\end{array}$} & $\begin{array}{l}\text { 86. Mampu mamahami konsep psikologi } \\
\text { pendidikan }\end{array}$ \\
\hline & $\begin{array}{l}\text { 87. Mampu merancang dan menggunakan } \\
\text { instrumentasi pada psikologi pendidikan }\end{array}$ \\
\hline & $\begin{array}{l}\text { 88. Mampu memahami praksis psikologi } \\
\text { pendidikan }\end{array}$ \\
\hline \multirow[t]{4}{*}{$\begin{array}{l}\text { 3. Menguasai teori belajar } \\
\text { dan pembelajaran }\end{array}$} & $\begin{array}{l}\text { 89. Mengidentifikasi teori pembelajaran dan } \\
\text { peruntukannya }\end{array}$ \\
\hline & $\begin{array}{l}\text { 90. Mengidentifikasi ciri khas perilaku belajar } \\
\text { peserta didik }\end{array}$ \\
\hline & $\begin{array}{l}\text { 91. Memahami perwujudan dan faktor-faktor } \\
\text { yang mempengaruhi perilaku belajar peserta } \\
\text { didik }\end{array}$ \\
\hline & $\begin{array}{l}\text { 92. Menguasai strategi pembelajaran untuk } \\
\text { mencapai tujuan pembelajaran }\end{array}$ \\
\hline \multirow{3}{*}{$\begin{array}{l}\text { 4. Menguasai tujuan, isi, } \\
\text { pengalaman belajar, dan } \\
\text { penilaian dalam kurikulum } \\
\text { satuan pendidikan }\end{array}$} & 93. Memahami tujuan dan isi kurikulum \\
\hline & $\begin{array}{l}\text { 94. Mengaplikasikan pengalaman belajar sesuai } \\
\text { kurikulum }\end{array}$ \\
\hline & $\begin{array}{l}\text { 95. Menguasai prinsip-prinsip evaluasi dalam } \\
\text { kurikulum di MI/SD }\end{array}$ \\
\hline \multirow{9}{*}{$\begin{array}{l}\text { 5. Menguasai konsep dan } \\
\text { metode keilmuan yang } \\
\text { menaungi substansi } \\
\text { bidang kajian pendidikan } \\
\text { dasar; }\end{array}$} & $\begin{array}{l}\text { 96. Menguasai konsep dan metode keilmuan } \\
\text { bahasa Indonesia pada jenjang pendidikan } \\
\text { dasar di MI/SD }\end{array}$ \\
\hline & $\begin{array}{l}\text { 97. Menguasai konsep dan metode keilmuan } \\
\text { matematika pada jenjang pendidikan dasar di } \\
\text { MI/SD }\end{array}$ \\
\hline & $\begin{array}{l}\text { 98. Menguasai konsep dan metode keilmuan } \\
\text { IPA pada jenjang pendidikan dasar di } \\
\text { MI/SD }\end{array}$ \\
\hline & $\begin{array}{l}\text { 99. Menguasai konsep dan metode keilmuan IPS } \\
\text { pada jenjang pendidikan dasar di MI/SD }\end{array}$ \\
\hline & $\begin{array}{l}\text { 100. Menguasai konsep dan metode keilmuan } \\
\text { PKn pada jenjang pendidikan dasar di } \\
\text { MI/SD }\end{array}$ \\
\hline & $\begin{array}{l}\text { 101. Menguasai substansi dan metodologi dasar } \\
\text { ilmu pendidikan jasmani, olahraga dan } \\
\text { kesehatan }\end{array}$ \\
\hline & $\begin{array}{l}\text { 102. Menguasai substansi dan metodologi dasar } \\
\text { keilmuan seni, budaya dan keterampilan yang } \\
\text { mendukung pembelajaran di MI/SD }\end{array}$ \\
\hline & $\begin{array}{l}\text { 103. Menguasai substansi dasar pembelajaran } \\
\text { bahasa Indonesia di MI/SD yang akan } \\
\text { dikemas melalui pembelajaran yang inovatif }\end{array}$ \\
\hline & 104. Menguasai substansi dasar pembelajaran \\
\hline
\end{tabular}




\begin{tabular}{|c|c|c|c|}
\hline & \multicolumn{2}{|r|}{$\begin{array}{l}\text { Matematika di MI/SD yang akan dikemas } \\
\text { melalui pembelajaran yang inovatif }\end{array}$} \\
\hline & & 105. & $\begin{array}{l}\text { Menguasai substansi dasar pembelajaran IPA } \\
\text { di MI/SD yang akan dikemas melalui } \\
\text { pembelajaran yang inovatif }\end{array}$ \\
\hline & & 106. & $\begin{array}{l}\text { Menguasai substansi dasar pembelajaran IPS } \\
\text { di MI/SD yang akan dikemas melalui } \\
\text { pembelajaran yang inovatif }\end{array}$ \\
\hline & & 107. & $\begin{array}{l}\text { Menguasai substansi dasar pembelajaran } \\
\text { PKn di MI/SD yang akan dikemas melalui } \\
\text { pembelajaran yang inovatif }\end{array}$ \\
\hline \multirow{2}{*}{\multicolumn{2}{|c|}{$\begin{array}{l}\text { 6. Menguasai konsep teori } \\
\text { bahasa dalam kehidupan } \\
\text { sehari-sehari sesuai } \\
\text { dengan nilai budaya } \\
\text { daerah yang berkarakter }\end{array}$}} & 108. & $\begin{array}{l}\text { Menguasai bahasa sesuai dengan budaya } \\
\text { daerah }\end{array}$ \\
\hline & & 109. & $\begin{array}{l}\text { Memiliki nilai-nilai etika yang meliputi } \\
\text { tanggungjawab, kerjasama, kejujuran, } \\
\text { pantang menyerah dan tolong menolong }\end{array}$ \\
\hline \multirow{6}{*}{\multicolumn{2}{|c|}{$\begin{array}{l}\text { 7. } \\
\text { Menguasai teori tentang } \\
\text { kependidikan, psikologi } \\
\text { pendidikan, psikologi } \\
\text { perkembangan anak, dan } \\
\text { pembelajaran yang } \\
\text { meliputi kurikulum, } \\
\text { perencanaan } \\
\text { pembelajaran, media } \\
\text { pembelajaran, strategi } \\
\text { pembelajaran, evaluasi } \\
\text { pembelajaran pada tingkat } \\
\text { pendidikan dasar MI/SD; }\end{array}$}} & 110. & $\begin{array}{l}\text { Memahami konsep, praksis dan praktik } \\
\text { psikologi pendidikan dan perkembangan } \\
\text { peserta didik di MI/SD }\end{array}$ \\
\hline & & 111. & $\begin{array}{l}\text { Memahami jenis-jenis dan mampu } \\
\text { mengaplikasikan bahan ajar pada pendidikan } \\
\text { dasar di MI/SD }\end{array}$ \\
\hline & & 112. & $\begin{array}{l}\text { Menguasai berbagai strategi pembelajaran di } \\
\text { MI/SD sesuai karakter peserta didik }\end{array}$ \\
\hline & & 113. & $\begin{array}{l}\text { Memahami konsep } \\
\text { pembelajaran serta mampu merancang } \\
\text { pembelajaran di MI/SD yang inovatif dan } \\
\text { kreatif }\end{array}$ \\
\hline & & 114. & $\begin{array}{l}\text { Menguasai prinsip-prInsip penilaian dan } \\
\text { proses pelaksanaan evaluasi pembelajaran } \\
\text { yang mengacu pada tujuan utuh pendidikan }\end{array}$ \\
\hline & & 115. & $\begin{array}{l}\text { Memiliki pengetahuan dalam merencanakan, } \\
\text { menyusun dan melaksanakan evaluasi } \\
\text { pembelajaran }\end{array}$ \\
\hline \multirow{3}{*}{\multicolumn{2}{|c|}{$\begin{array}{l}\text { 8. Menguasai teori tentang } \\
\text { pembelajaran tematik di } \\
\text { MI/SD; }\end{array}$}} & 116. & $\begin{array}{l}\text { Mengetahui pengintegrasian tema dalam } \\
\text { pembelajaran tematik }\end{array}$ \\
\hline & & 117. & $\begin{array}{l}\text { Menguasai teori pembelajaran tematik sesuai } \\
\text { dengan tahapan perkembangan peserta didik } \\
\text { di MI/SD }\end{array}$ \\
\hline & & 118. & $\begin{array}{l}\text { Memiliki pengetahuan dalam merencanakan, } \\
\text { mendesain dan melaksanakan pembelajaran } \\
\text { tematik di MI/SD yang inovatif dan kreatif }\end{array}$ \\
\hline & $\begin{array}{l}\text { Memahami konsep } \\
\text { pendidikan dasar di } \\
\text { MI/SD dengan }\end{array}$ & 119. & $\begin{array}{l}\text { Memahami konsep bahasa Indonesia di } \\
\text { MI/SD dengan berlandaskan nilai-nilai } \\
\text { keislaman }\end{array}$ \\
\hline
\end{tabular}


berlandaskan nilai-nilai ke-Islaman.

\begin{tabular}{ll}
\hline 120. & $\begin{array}{l}\text { Memahami konsep matematika di MI/SD } \\
\text { dengan berlandaskan nilai-nilai keislaman }\end{array}$ \\
\hline 121. & $\begin{array}{l}\text { Memahami konsep IPA di MI/SD dengan } \\
\text { berlandaskan nilai-nilai keislaman }\end{array}$ \\
\hline 122. & $\begin{array}{l}\text { Memahami konsep IPS di MI/SD dengan } \\
\text { berlandaskan nilai-nilai keislaman }\end{array}$ \\
\hline 123. & $\begin{array}{l}\text { Memahami konsep PKn di MI/SD dengan } \\
\text { berlandaskan nilai-nilai keislaman }\end{array}$ \\
\hline 124. & $\begin{array}{l}\text { Memahami konsep seni budaya di MI/SD } \\
\text { dengan berlandaskan nilai-nilai keislaman }\end{array}$ \\
\hline
\end{tabular}

KETERAMPILAN KHUSUS

1. Mengidentifikasi

karakteristik peserta didik dari aspek fisik,

125. Mampu mengidentifikasi karakteristik peserta didik dari aspek fisik dan psikologis untuk psikologis, sosial, dan 126. Mampu mengidentifikasi karakteristik peserta kultural untuk kepentingan pembelajaran;

2. Memberikan layanan kepada peserta didik sesuai dengan karakteristiknya;

127. Mampu memberikan layanan administrasi pada penyelenggaraan pendidikan didik dari aspek sosial, dan kultural dalam proses pembelajaran karakteristik peserta didik

129. Mampu merancang dan menerapkan dasardasar bimbingan konseling untuk memecahkan masalah

3. Mengembangkan potensi peserta didik secara optimal;

130. Mampu merancang program untuk mengembangkan keunggulan/potensi setiap peserta didik

131. Mampu memahami/mengenali karakter, minat, dan potensi peserta didik

132. Mengarahkan minat dan bakat secara positif dan berkelanjutan

4. Mengaplikasikan teori pembelajaran di MI/SD;

133. Mengaplikasikan teori pembelajaran berdasarkan perkembangan peserta didik di $\mathrm{MI} / \mathrm{SD}$

134. Memecahkan permasalahan peserta didik dalam proses pembelajaran di MI/SD

5. Menganalisis kurikulum pada pendidikan dasar $\mathrm{MI} / \mathrm{SD}$

135. Mengimplementasikan proses pembelajaran sesuai dengan kurikulum pendidikan dasar $\mathrm{MI} / \mathrm{SD}$

136. Mengembangkan kurikulum berbasis karakter peserta didik

6. Mengaplikasikan teori psikologi perkembangan

137. Mengaplikasikan perkembangan di MI/SD di MI/SD 


\begin{tabular}{|c|c|c|c|}
\hline & $\begin{array}{l}\text { Mengaplikasikan teori } \\
\text { psikologi pendidikan di } \\
\text { MI/SD }\end{array}$ & 138. & $\begin{array}{l}\text { Mengaplikasikan teori psikologi pendidikan } \\
\text { di MI/SD }\end{array}$ \\
\hline \multirow[t]{2}{*}{8.} & \multirow[t]{2}{*}{$\begin{array}{l}\text { Mendesain strategi } \\
\text { pembelajaran di MI/SD }\end{array}$} & 139. & $\begin{array}{l}\text { Mendesain media pembelajaran sesua } \\
\text { dengan strategi dalam proses pembelajaran }\end{array}$ \\
\hline & & 140. & $\begin{array}{l}\text { Mendesain strategi pembelajaran sesua } \\
\text { dengan karakter peserta didik di MI/SD }\end{array}$ \\
\hline \multirow[t]{2}{*}{9.} & \multirow{2}{*}{$\begin{array}{lr}\text { Merancang dan } \\
\text { mengaplikasikan teori } \\
\text { manajemen pendidikan di } \\
\text { MI/SD } \\
\end{array}$} & 141. & $\begin{array}{l}\text { Merancang manajemen pendidikan dasar di } \\
\text { MI/SD }\end{array}$ \\
\hline & & 142. & $\begin{array}{lrl}\text { Mengaplikasikan teori } & \text { manajemen } \\
\text { pendidikan dasar di MI/SD }\end{array}$ \\
\hline \multirow[t]{2}{*}{10} & \multirow[t]{2}{*}{$\begin{array}{l}\text { Mempersiapkan dan } \\
\text { menerapkan media } \\
\text { pembelajaran di MI/SD; }\end{array}$} & 143. & $\begin{array}{l}\text { Merancang media pembelajaran di MI/SD } \\
\text { yang kreatif, inovatif dan sesua } \\
\text { perkembangan teknologi }\end{array}$ \\
\hline & & 144. & $\begin{array}{l}\text { Memahami media pembelajaran di MI/SD } \\
\text { yang kreatif, inovatif dan sesua } \\
\text { perkembangan teknologi }\end{array}$ \\
\hline \multirow[t]{2}{*}{11.} & \multirow{2}{*}{$\begin{array}{l}\text { Merancang dan } \\
\text { menerapkan evaluasi } \\
\text { pembelajaran di MI/SD; }\end{array}$} & 145. & Merancang evaluasi pembelajaran di MI/SD \\
\hline & & 146. & $\begin{array}{l}\text { Menerapkan proses evaluasi pembelajaran } \\
\text { pendidikan dasar MI/SD }\end{array}$ \\
\hline \multirow[t]{5}{*}{12} & \multirow{5}{*}{$\begin{array}{l}\text { Mengaplikasikn keilmuan } \\
\text { guru kelas MI/SD dengan } \\
\text { bidang kajian Bahasa } \\
\text { Indonesia, Matematika, } \\
\text { IPA, IPS, dan PKn; }\end{array}$} & 147. & $\begin{array}{l}\text { Mengaplikasikan bidang kajian bahasa } \\
\text { Indonesia di MI/SD yang inovatif, kreatif } \\
\text { dan menyenangkan }\end{array}$ \\
\hline & & 148. & $\begin{array}{l}\text { Mengaplikasikan bidang kajian matematika d } \\
\text { MI/SD yang inovatif, kreatif dan } \\
\text { menyenangkan }\end{array}$ \\
\hline & & 149. & $\begin{array}{l}\text { Mengaplikasikan } \\
\text { MI/SD yang } \\
\text { menyenangkan }\end{array}$ \\
\hline & & 150. & $\begin{array}{ll}\text { Mengaplikasikan } & \text { bidang kajian IPS di } \\
\text { MI/SD yang } & \text { inovatif, kreatif dan } \\
\text { menyenangkan } & \end{array}$ \\
\hline & & 151. & $\begin{array}{l}\text { Mengaplikasikan bidang kajian PKn d } \\
\text { MI/SD yang inovatif, kreatif dan } \\
\text { menyenangkan }\end{array}$ \\
\hline \multirow[t]{3}{*}{13.} & \multirow[t]{3}{*}{$\begin{array}{l}\text { Mengaplikasikan teori } \\
\text { pembelajaran tematik di } \\
\text { MI/SD; }\end{array}$} & 152. & $\begin{array}{l}\text { Menguasai pengintegrasian } \\
\text { kompetensi dari beberapa mata } \\
\text { dengan mengguajakan tema }\end{array}$ \\
\hline & & 153. & $\begin{array}{l}\text { Merencanakan, mendesain dan melaksanakan } \\
\text { pembelajaran tematik di MI/SD yang } \\
\text { inovatif dan kreatif }\end{array}$ \\
\hline & & 154. & $\begin{array}{l}\text { Mengaplikasikan teori pembelajaran tematik } \\
\text { sesuai dengan tahapan perkembangan peserta } \\
\text { didik di MI/SD }\end{array}$ \\
\hline 14. & $\begin{array}{l}\text { Mampu memberikan } \\
\text { solusi dalam memecahkan }\end{array}$ & 155. & $\begin{array}{l}\text { Memberikan arahan terkait pengelolaan } \\
\text { kurikulum dan pembelajaran, } \\
\text { pengelolaan }\end{array}$ \\
\hline
\end{tabular}




\begin{tabular}{ll}
\hline masalah terkaitan & kelas, pengelolaan peserta didik, \\
pengelolaan pendidikan & pengelolaaan SDM, pengelolaan sarana dan \\
dasar MI/SD. & prasarana dan pengelolaan keuangan di \\
& MI/SD untuk mencapai tujuan pendidikan \\
\cline { 2 - 3 } & Memberikan solusi terhadap berbagai \\
& masalah terkait pengelolaan pendidikan dasar \\
& di MI/SD yang dapat menghambat tujuan \\
& pendidikan \\
\hline
\end{tabular}

Kemudian adapun struktur kurikulum KKNI Jurusan Pendidikan Guru Madrasah Ibtidaiyah IAIN Metro sebagai berikut:

\section{Tabel 2. Struktur Kurikulum KKNI Jurusan PGMI}

\begin{tabular}{clr}
\hline No & \multicolumn{1}{c}{ Kelompok Mata Kuliah } & SKS \\
\hline 1 & Mata Kuliah Institusi (MKI) & 29 \\
\hline 2 & Mata Kuliah Fakultas (MKF) & 29 \\
\hline 3 & Mata Kuliah Program Studi (MKPS) & 77 \\
\hline & 3.1. Mata kuliah Program Studi (Wajib) & $18^{*}$ \\
\cline { 2 - 3 } 3.2. Mata kuliah Program Studi (Pilihan) & 153 \\
\cline { 2 - 2 } JUMLAH & Catatan:*Mahasiswa wajib mengambil mata kuliah pilihan minimal 9
\end{tabular}

Selanjutnya untuk merealisasikan pencapaian pembelajaran yang terdiri dari aspek sikap secara umum dapat ditumbuhkan melalui mata kuliah kepribadian, antara lain Pancasila, Al-Qur'an Hadits, Fiqh Ibadah, Aqidah Akhlak, Bahasa Indonesia, Kewarganegaan. Isi mata kuliah tersebut harus bisa menumbuhkan nilai-nilai karakter, kepribadian, sikap dalam berkarya, etika, dan moral.

Capaian pembelajaran berupa pengetahuan dapat diperoleh dengan menguasai teori tentang kependidikan, Psikologi Pendidikan, Psikologi Perkembangan Anak, dan Pembelajaran yang meliputi Kurikulum, Perencanaan Pembelajaran, Media Pembelajaran, Strategi Pembelajaran, Evaluasi Pembelajaran Pada Tingkat Pendidikan Dasar MI/SD; Pembelajaran Tematik, Psikologi Perkembangan dan lain sebagainya. Sedangkan capaian pembelajaran dari aspek keterampilan khusus dan umum dapat diperoleh dengan menguasai teori dan praktik mata kuliah keprodian dan mata kuliah pilihan.

\section{PEMBAHASAN}

\section{Analisa Muatan Kurikulum PGMI}

Mencermati peluang kerja bagi guru Sekolah Dasar atau Madrasah Ibtidaiyah yang cukup menjaiikan. Jurusan PGMI terus berupaya meningkatkan 
mutu jurusan dengan cara mengikuti perkembangan kurikulum di pendidikan tinggi. perkembangan kurikulum yang diberlakukan di jurusan PGMI antara lain kurikulum 2008 untuk angkatan 2014 ke atas. Kurikulum 2014 berbasis KKNI untuk angkatan 2015 sd 2017 dan yang terbaru Kurikulum KKNI untuk mahasiswa angkatan 2018.

Perkembangan kurikulum yang terus diberlakukan ditunjang dengan menjalin komunikasi dengan Asosiasi dosen PGMI seluruh Indonesia. hal ini dilakukan untuk menyamakan profil lulusan untuk jurusan PGMI yaitu sebagai guru kelas Sekolah Dasar atau Madrasah Ibtidaiyah atau sederajat.

Berpijak pada beberapa teori tentang kurikulum yang menjelaskan bahwa kurikulum merupakan rancangan pengajaran yang isinya sejumlah mata pelajaran yang disusun secara sistematis sebagai syarat untuk menyelesaikan program pendidikan tertentu.10 atau kurikulum bukan hanya sekedar memuat sejumlah mata pelajaran, namun termasuk didalamnya segala usaha yang dilakukan baik itu di dalam kelas atau di luar kelas untuk mencapai tujuan yang diinginkan.11 Maka untuk relevansi kurikulum jurusan PGMI terhadap muatan mata kuliah telah sesuai, sebagai buktinya antara lain:

a. Kurikulum 2008

Capaian pembelajaran berupa kompetensi mahasiswa yang diukur dengan cara setiap mata kuliah diurai berdasar Standar Kompetensi (SK) dan Kompetensi Dasar (KD). Sedangkan muatan mata kuliah juga telah disesuaikan dengan amanat UNESCO tentang empat pilar pendidikan dan disesuaikan dengan Keputusan Mendiknas No. 232/U/2000, yang teruraikan sebagaimana berikut: 1) MPK (Mata Kuliah Pengembangan Kepribadian), 2)MKK (Mata Kuliah Keilmuan dan Keterampilan), 3) MKB (Mata Kuliah Keahlian Berkarya), 4) MPB (Mata Kuliah Perilaku Berkarya), 5) MBB (Mata 6) MKPK (Mata Kuliah Pilihan Konsentrasi)

b. Kurikulum 2014 berbasis KKNI telah direvisi dengan kurikulum KKNI yang diberlakukan mulai angkatan 2018.

c. Kurikulum KKNI. Penetapan capaian pembelajaran menggunakan tiga rujukan, yaitu (KKNI), (SNPT) dan (SNPG). Untuk selanjutnya rumusan capaian pembelajaran dijabarkan dalam Standar Kopetensi Lulusan (SKL) yang dinyatakan dalam empat unsur yaitu : sikap, keterampilan umum, pengetahuan dan keterampilan khusus. aspek sikap secara umum dapat ditumbuhkan melalui muatan mata kuliah kepribadian, antara lain pancasila, al-qur'an hadits, fiqh ibadah, aqidah akhlak, bhs indonesia, kewarganegaan. Isi mata kuliah tersebut harus bisa menumbuhkan nilai-nilai karakter, kepribadian, sikap dalam berkarya, etika, dan moral. Capaian pembelajaran berupa pengetahuan dapat diperoleh dengan menguasai teori tentang

10 Fauzan, Kurikulum \& Pembelajaran, (Tangerang Selatan : Gaung Persada (GP) Press, 2017), 55.

11 S. Nasution, Kurikulum dan Pengajaran, (Jakarta : PT Bumi Aksara 2012), 9. 
kependidikan, psikologi pendidikan, psikologi perkembangan anak, dan pembelajaran yang meliputi kurikulum, perencanaan pembelajaran, media pembelajaran, strategi pembelajaran, evaluasi pembelajaran pada tingkat pendidikan dasar MI atau SD; pembelajaran tematik, psikologi perkembangan dan lain sebagainya. Sedangkan capaian pembelajaran dari aspek keterampilan khusus dan umum dapat diperoleh dengan menguasai teori dan praktik mata kuliah keprodian dan mata kuliah pilihan.

\section{KESIMPULAN}

Penetapan capaian pembelajaran kurikulum jurusan PGMI IAIN Metro menggunakan tiga rujukan, yaitu KKNI, Standar Nasional Perguruan Tinggi (SNPT) dan Standar Nasional Pendidikan Guru (SNPG). Untuk selanjutnya rumusan capaian pembelajaran dijabarkan dalam Standar Kopetensi Lulusan (SKL) yang dinyatakan dalam empat unsur yaitu : sikap, keterampilan umum, pengetahuan dan keterampilan khusus. Aspek sikap secara umum dapat ditumbuhkan melalui muatan mata kuliah kepribadian. Aspek pengetahuan dapat diperoleh dengan menguasai teori tentang kependidikan, psikologi dan pembelajaran. Dan aspek keterampilan khusus dan umum dapat diperoleh dengan menguasai teori dan praktik mata kuliah keprodian dan mata kuliah pilihan. Dengan demikian dapat disimpulkan muatan kurikulum PGMI sudah relevan dengan capaian pembelajaran mahasiswa PGMI IAIN Metro.

\section{DAFTAR PUSTAKA}

Depdiknas, Buku Pedoman Kerangka Kualifikasi Nasional Indonesia, Jakarta: Direktorat Jendral Pendidikan Tinggi, 2010.

Fauzan, Kurikulum \& Pembelajaran, Tangerang Selatan : Gaung Persada (GP) Press, 2017.

Imroatus Solikhah "KKNI Dalam Kurikulum Berbasis Learning Outcome" dalam LINGUA, Vol 12, No. 1 Maret 2015.

Kurikulum Berbasis Kerangka Kualifikasi Nasional Indonesia (KKNI) Prodi PAI, PBA, PBI dan PGMI Jurusan Tarbiyah. Sekolah Tinggi Agama Islam Nergeri (STAIN) Jurai Siwo Metro 2014.

S. Nasution, Kurikulum dan Pengajaran, Jakarta : PT Bumi Aksara 2012.

Surat Keputusan Direktur Jenderal Pendidikan Islam Departemen Agama RI Nomor Dj.I/257/2007 tentang Izin Penyelenggaraan Program Pendidikan Guru Madrasah Ibtidaiyah (PGMI) Jenjang Strata Satu (S1) pada Perguruan Tinggi Agama Islam (PTAI). 
82| Ar-Riayah : Jurnal Pendidikan Dasar Vol. 3, No. 1, 2019

Surat Keputusan Direktur Jenderal Pendidikan Islam Departemen Agama RI Nomor Dj.I/485/2009 tentang perpanjangan izin penyelenggaraan program studi Pendidikan Guru Madrasah Ibtidaiyah (PGMI) jenjang Strata Satu (S1) pada Perguruan Tinggi Agama Islam Negeri (PTAIN)

Surat Keputusan Direktur Jenderal Pendidikan Islam Nomor 561 tahun 2009 tentang perpanjangan izin penyelenggaraan program studi Pendidikan Guru Madrasah Ibtidaiyah (PGMI) jenjang Strata Satu (S1) pada Perguruan Tinggi Agama Islam Negeri (PTAIN) Tahun 2012 pada tanggal 15 Mei 2012.

Tim K-DIKTI, Buku Kurikulum Pendidikan Tinggi Direktorat Pembelajaran dan Kemahasiswaan, Jakarta: Direktorat Jenderal Pendidikan Tinggi Kementerian Pendidikan dan Kebudayaan, 2014.

Palm Beach State College, "Academic Management Manual: Outcomes AssessmentWorkbook."2013.8Availableat:www.palmbeachstate.edu/academi cservices/documents/sectionl.pdf. diunduh tgl 01 Oktober 2018

Peraturan Menteri Agama Republik Indonesia tentang Standar Kompetensi Lulusan pada Perguruan Tinggi Agama Islam Tahun 2012. 